\title{
Informal Team Learning: A Case Study in Knowledge-Intensive Settings
}

\section{Roza Marsaulina Sibarani}

School of Business and Management, Bandung Institute of Technology roza@sbm-itb.ac.id

\section{Professor Dr. Jann Hidajat Tjakraatmadja}

School of Business and Management, Bandung Institute of Technology

\section{Professor Utomo Sarjono Putro, PhD}

School of Business and Management, Bandung Institute of Technology

\section{Dr. Ningky Sasanti Munir}

PPM School of Management

Doi:10.5901/mjss.2015.v6n5p381

\begin{abstract}
We tend to learn in an informal way before we do it formally. We learn to walk or ride a bike when we were children before we went to formal school. In organization, learning is essential to improve the performance, and informal learning complements formal training. Having an informal discussion in an office lounge or chat in a workgroup messenger application are some informal learning activities. This paper seeks to explore and help leaders to gain insights into the effective informal learning in the workplace especially in knowledge-intensive settings. Critical success factors of effective informal learning have been defined: informal learner that do informal learning within their team, the role of team leader that facilitates learning and team climate that support informal learning processes. Literature study and qualitative case study was conducted in a mid-size consulting firm in Indonesia. Data collection was based on semi-structured interviews to 21 respondents. We found a research model that can be applied by leader for promoting an effective informal learning strategy and process.
\end{abstract}

Keywords: Effective Team, Informal Learning, Informal Learner, Team Learning, Team Leadership, Team Climate

\section{Introduction}

In a workplace setting, professional expertise is more often credited through formal training, but some studies showed that only $20 \%$ of what employees learn came from formalized and structured training (Marsick \& Watkins, 1990; Cross, 2007). Lombardo and Eichinger's research, at Center for Creative Leadership, found a 70:20:10 model in 1980s, which showed that learning was done by assignments (70\%), relationships (20\%) and formal courses (10\%) (Kajewski \& Madsen, 2012).

Informal learning is important for business. It financially affects the organization because it can reduce its learning costs and become a future (Conlon, 2004). In fact, it suggested to recruit informal learners, who require less formal training and are hungry for new experiences, because they can be more easily developed (Gorard et al, 1999). A study showed that $21 \%$ of executives ask for informal learning impact measurement and this is expected to rise (Knowledge Advisors, 2010).

Teams are a key-learning unit in an organization (Senge et al, 1990; Tjakraatmadja \& Lantu, 2006). Creating and improving team learning can directly influence organizational learning (Edmondson, 1999). The object of this paper is to study informal learning processes in a team in knowledge intensive organization, and to develop an effective informal team learning model. This research is conducted based on literature studies and case studies in a medium-sized Indonesian professional services firm. However this paper is a preliminary stage for future research. Future research should be developed using a broader sample from the winners of Indonesia Most Admired Knowledge Enterprise (MAKE) Study during 1995-2014 period. 


\section{Literature Review}

\subsection{Informal learning in the workplace}

Informal learning started as a part of psychological studies, based on a view that people can do things without going to formal classes (Gola, 2009). The implementation had been studied in educational institutions and corporations. A study showed that informal learning was done by asking questions to seniors and practicing different tasks in schools and universities (Marsick \& Watkins, 2003).

In business, informal learning is not inferior to formal learning, instead they complement to each other (Svensson et al, 2004). It has been studied to professionals in UK (Cheetham \& Chivers, 2001) and, specifically, bankers in London (Chivers, 2010) that showed that most of the works improved by informal and incidental learning, and only a few from formal learning. In non-profit organizations, a study on social workers in Italy showed that informal learning was done in individual level (Gola, 2009). And Informal learning had also been studied in specific business situations such as restructuring, merger, and downsizing (Reardon, 2004).

Sources of informal learning in team levels include efforts to use informal learning technology in project teams (Svensson et al, 2004; Nirmala \& Vemuri, 2009) and relations between community of practitioners and informal learning (Boud \& Middleton, 2003). Meanwhile, Advanced Distributed Learning (ADL) Initiatives in the US had developed open source Sharable Content Object Reference Model (SCORM) software since 2004 that helped a single learner to improve learning quality by tailoring it to individual needs (Advanced Distributed Learning, 2012).

Since there is no previous study about informal learning for work-based teams in knowledge-intensive settings, this research is considered as an important attempt to investigate this. This paper defines informal learning as a learning process that is done informally that can be unplanned and spontaneous. It uses social media as a supporting tool, while the subjects are limited to professional workers.

Q: How to create a model of effective informal team learning?

\subsection{Informal learner}

The study of Coraldyn and Bjornavold (2004) showed that the individual has an important role in informal learning. The individual is the center of a learning process and he will learn if he is supported by leadership, goals, personal development, and rewards (Marsick \& Watkins, 2003).

To learn fast and effectively, individuals should have suitable capabilities. McNally et al (2009) studied new schoolteachers and found that some dimensions of competence to informal learning, i.e. emotional dimension (emotional level), relational dimension (ability to build relationships with others), and professional dimension (competence to learn informally and accomplish tasks). In relation to professional dimensions, a study on hospital nurses showed that younger nurses would learn a lot if they were given more responsibility and were mentored by their seniors in difficult situations (Bjork et al, 2013).

Those dimensions are similar to what Ryan et al (2009) found in their study in distinguishing high-performing European Union managers, whose emotional, social and cognitive competencies are very crucial in workplace. In professional dimensions, intellectual and technical skills are important for young workers. Gradually, these skills will be replaced by experience and expertise.

\subsection{Team leadership as a facilitator for reinforcing informal learning}

The literature that talks about leadership roles in team learning are grouped into learning environment creation (Marsick \& Watkins, 1990, 2003) and learning behaviours development (Marquardt, 2000; Marsick \& Watkins, 2003; Edmondson et al, 2006; Herre, 2010). Learning environment can be created if the employees are able to cooperate and make innovations (Ellinger \& Cseh, 2007). Leadership can indeed influence learning process even on the lowest level, such as front liners (Macneil, 2001). Since the learner himself takes control in informal learning, a leader acts as a learning facilitator only.

Popular leadership styles that motivate people to learn are transactional and transformational leaderships (Nailon et al, 2007). However, implementing a transactional style will negatively influence a team's innovativeness (Liu et al, 2011) and it leaves very little room for employees to be engaged and motivated (Nailon et al, 2007).

There are many leadership approaches. One of them that can foster knowledge sharing and team efficacy is empowering leadership (Srivastava et al, 2006). Empowering behaviour of a leader motivates others to engage in 
knowledge activities, sets a high performance level, shares knowledge openly, provides autonomy and helps in solving problem (Chuang et al, 2013).

Empowering leadership behaviours, according to Arnold et al (2000), are leading by example (walk the talk), participative decision-making (encourage others to share ideas), coaching (help others to define common goals and take collective and appropriate action), informing (inform employees of a clear team goal and provide information access to goals) and showing concern for the team (show respect and attention).

\subsection{Team climate as a supportive informal learning environment}

To develop a good habit requires a good habitat. Habitat or climate may influence individuals to collaborate (Hult et al, 2002; Reychav \& Weisberg, 2009) and commit themselves to teach (Cunningham \& lles, 2002). Edmondson (1999) studied relationships between learning habitat and behaviours in 53 teams and introduced the importance of psychological safety, which is similar to interpersonal climate and shared beliefs for team knowledge sharing.

At an interpersonal level, tension often arises from team learning among individuals. High levels of emotional intelligence enable individuals to be aware and manage their emotions when interacting with others. It also influences psychological safety in teams (Ghosh et al, 2010).

Related to human capital system, surprisingly, rewards do not significantly motivate learning (Reardon, 2009). Incentives or rewards can be attractive for some people, but they are more effective when a person shares knowledge that has been used by another person (lyer \& Ravindran, 2009).

Another team climate research did by Anderson and West in 1994 that developed team climate inventory (TCI). It is commercially available that had 5 key factors, i.e. participant safety, support for innovation, vision, task orientation and social desirability. This measurement tool can help teams to diagnose their attitudes and work processes.

\subsection{Team Effectiveness}

Team effectiveness is modelled as Input-Process-Output (IPO), and effective means the balance process from input to output. The IPO model provides a framework to visualize the influence of team outcomes, but we need to focus on each factor (Herre, 2010). In this study, informal learner, leadership and team climate are dimensions of input and process factors.

Many researchers use team performance as an output, although it is difficult to come up with a conclusive concept of team performance. It can be financial, operational or behavioural outcomes. In a study on 142 innovation project teams, performance is defined as task accomplishment (Kostopoulos \& Bozionelos, 2011). In non-profit organizations, learning output is measured by knowledge performance and mission accomplishment (Prugsamatz, 2010; Ross et al, 2008). In a conceptual study on team learning in process perspectives, performance is defined as team-learning behaviour (Edmondson et al, 2006).

In earlier research, Gladstein (1984) defined team effectiveness results as performance and employee satisfaction. Later, Hackman (1990) defined it as performance (quality, quantity and delivery timeliness), behaviour (team members' ability improvement) and attitude (individual satisfaction being in a team).

\section{Research Model}

Considering the characteristics of informal learning, we have illustrated the conceptual model of our study in Figure 1 for data collection. Effective informal team learning is the outcome that will be achieved by a team consisting of multigenerational members. And it is influenced by three variables that relate to the informal learner as the learning actors, team leader as a facilitator to reinforce informal learning, and team climate as supportive informal learning environment.

The dimensions or attributes for each variable in conceptual model will be investigated in qualitative study. The questionnaire for qualitative study is created based on previous literature review study as showed in table 1. 


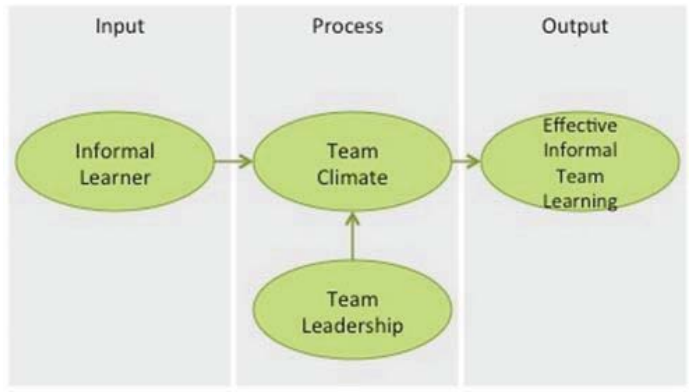

Figure 1. Conceptual model based on Literature Review Study

Table 1. Qualitative Research Based on Literature Review Studies

\begin{tabular}{lll}
\hline Variable & Literature Support & Dimensions \\
\hline Informal learner & Ryan et al (2009); McNally (2009); Cunningham \& lles, 2002 & $\begin{array}{l}\text { Trustworthy } \\
\text { Open minded } \\
\text { Eager to learn and share } \\
\text { knowledge } \\
\text { Take initiative }\end{array}$ \\
& & Adaptability \\
& & Innovative \\
Team Leadership & Bjork et al (2013), Chuang et al (2013); Ellinger \& Cseh & Role model \\
& (2007); Arnold (2000) & Open \\
& & Flexible \\
& & Giving guidance \\
& & Motivating others to learn \\
& Ghosh et al (2010); Edmondson (2006, 1999); Cunningham & Trust each other's \\
& Openness \\
& L lles (2002); Anderson \& West (1994) & Learn and share knowledge \\
& & Supported system and facilities \\
& & Faster tasks accomplishment \\
\end{tabular}

\section{Methodology}

This study aims to do in-depth exploratory investigation in a holistic situation, and it uses a single-case study methodology. Single-case is commonly used to confirm and challenge a theory and to show validity for both exploratory and explanatory designs (Yin, 1994). Yin (1994) also suggests using multiple sources of evidence for validation. To ensure that the case is well structured and analysed, two steps have been done:

1. Semi-structured interviews with selected team leaders and team members: The observed consulting firm has 138 full-time employees. Twenty-one employees were identified as key learning contributors in their team and were interviewed. They were team leaders and team members from business, technical and support functions. Questionnaires in the interviews explored information on informal learning behaviours and activities. Interviews were recorded and transcribed in verbatim using NVIVO 10 software for analysis.

2. Findings validation: Meeting with team leaders and members were done on a regular basis to discuss the findings. For team leaders, it gave insights about team situations and created opportunities for improvement. It also made team members realize that informal learning can support their work and create opportunities to be more effective. 
Table 2. Socio-demography characteristics of interviewees $(\mathrm{N}=21)$

\begin{tabular}{llcc}
\hline Demographic Variable & Categories & $\mathrm{N}$ & $\%$ \\
\hline \multirow{2}{*}{ Gender } & Male & 6 & $29 \%$ \\
& Female & 15 & $71 \%$ \\
\multirow{3}{*}{ Work experience } & $1-5$ years & 4 & $19 \%$ \\
& $6-10$ years & 3 & $14 \%$ \\
\multirow{3}{*}{ Leader position } & $11-15$ years & 8 & $38 \%$ \\
& $16-20$ years & 3 & $14 \%$ \\
Team function & $>21$ years & 3 & $14 \%$ \\
& Team leader & 5 & $24 \%$ \\
& Team member & 16 & $76 \%$ \\
& Business team & 6 & $29 \%$ \\
& Technical team & 8 & $38 \%$ \\
& Support team & 7 & $33 \%$ \\
\hline
\end{tabular}

\section{Results}

This consulting firm aims to enable greatness in individuals and organizations through its consulting, training and assessment services. They develop and contextualize training and consulting solutions. Its business process determines three functions of work units, i.e. business, technical and support team.

\subsection{Informal learning in practice}

All of the individual and team have to deal with knowledge in their daily activities, and they have to learn informally in their work. In a business team, for instance, they should understand clients' business, relate it with industrial knowledge for diagnosing clients' needs and have quite a deep knowledge of 50 solution options for proposing the right solution. Each new sales person should gain knowledge, in a short amount of time, about the client and their relationship, and about the solutions. Although there is a formal induction program, informal learning helps them to learn faster.

The human capital department has created formal programs to overcome this situation, such as a personal development program including training and mentoring, exit interview, and a weekly product knowledge sharpening session from the technical to business team. The IT system was prepared to support business activities such as Lotus Notes intranet portal and intranet database. All of this knowledge is obtained in database, so anyone can explore, download, use and share documents.

Even so, those formal systems were not enough for employees to do their job. One of the senior employees from the business team said: "We work fast so we need knowledge quickly. Clients want us to submit a proposal within a week; hence we need to find the right solution straight away. If we wait until a product knowledge sharing session, we will not fulfil the client's needs. What we did was ask the product manager directly. We discussed solutions informally with her by having a cup of coffee in office lounge."

The technical team also needs to find information and learn fast to do the job. A new trainer should learn the solutions within three months and be able to deliver the program by himself. A consultant team takes and shares knowledge during project delivery. For instance, when delivering a consulting project for a public institution, the project manager updated his team's knowledge using online messenger.

Since there are many routines job in supporting team, they rarely learn informally. Most of accounting, finance and IT jobs are done in routine. The human capital officer sometimes has to be creative i.e. in organizing internal events. Therefore, she often has discussions with her colleagues, both by face to face or with the messenger application.

Although most of employees have done informal learning in their daily activities, some of them still have difficulties in integrating a leadership style, generation $\mathrm{Y}$ behaviour and team climate.

\subsection{Informal learner}

As the center of informal learning activities (Coraldyn \& Bjornavold, 2004), each individual is supposed to have the urge to learn informally. They are knowledge workers and they need to learn and share knowledge to do their job. They are not forced by the leader or by others to learn.

In our case study, all of the interviewees are knowledge workers. They are already used to capturing, expanding, 
applying and sharing knowledge with each other. Initially, they are encouraged to learn informally to do their job. In their opinion, most of their colleagues are also knowledge workers and have done informal learning. However, some of them still need guidance to do it properly and need to improve their analytical capability. And some of them often do informal learning and some other infrequently due to the job type.

When we asked about the indicators of an individual to be a good informal learner, some of the interviewees came up with the character and competence of individuals. The individual should be a trusted person; otherwise the other workers will not share with him nor learn from him. Two interviewers from technical department mentioned that trustworthy is a basic and not necessarily put as an indicator.

Individual should also open minded to be able to discuss, exchange ideas and learn from others. As a knowledge worker, he is eager to learn and to share knowledge. To learn effectively, he should have an adaptability skill to tolerate and adapt to his colleagues and changes. Take initiative is also an important indicator to become an informal learner. In this firm, it is already embedded as one of the corporate culture values.

Nine team members and two team leaders were mentioned innovative as an important indicator of informal learner as shown in Table 3. "We need to contextual solutions for clients therefore we need to be innovative. Being innovative needs informal learning and innovative drives people to learn informally," said a consultant. He also added that innovative capability in that firm still need to be improved.

Furthermore, some of team leader said the importance of analytical thinking capability. If an individual has good analytical thinking, he will able to find the right information quick and analyse it properly.

\subsection{Team leadership}

All of the interviewees agree that leadership is a key factor in creating and maintaining an informal learning environment. When we asked about the ideal way to lead, the first answer of majority interviewees was role modelling. A leader is expected to be open, which means that he has to be transparent, has no hidden agenda, can be reached easily and is open to discuss with others. If a leader is not open, then an informal situation will be difficult to be created. People will get tense when they are having a discussion with him. He also restricts his contacts with others and restrains himself from many outer influences.

As each individual is different, a leader is requested to be flexible with his team members' learning style. Freedom to learn is important to young workers and a leader can only monitor learning progress and results. A leader is also expected to have connection to various sources like experts and literatures in order to give guidance to his team members. All respondents said that they need motivation from the leader to learn. The motivation is simply a reminder to keep learning and sharing knowledge. And young workers respondents said that they still need guidance from their leaders.

However team leaders said that informal learner does not have to be motivated to learn because he has eagerness to learn and share knowledge by himself. Besides, they said that leader should have clear vision and influence team members to reach it together. On the other side, some of team members added that leaders should know the strengths of each member and have plan to develop each of them.

\subsection{Team climate}

All interviewees agree that creating informal learning habits need to be conducive to the environment. It starts with the individuals within the team, to the facilities, and the company system. First of all, team members and the leader should trust each other so that they can share knowledge openly. The more trusted a person is to others, the more readily he receives or gives ideas. Also, when there is mutual trust within the team it is much easier to build togetherness, and this is important in creating informal situations.

Togetherness can also be encouraged by the openness where there is no silo in team or sub team. Some interviewees said that a person might have preference and feel more comfortable and close to group of people, but not to cause silo with other groups.

In order to create a learning climate, interviewees also said the importance of willingness to learn and share knowledge with others. An interviewee said that:

"Some people in my team want to share, but they do not spontaneously to do it rather should be provoked first."

Related to facilities and systems, all interviewees said that the office environment supported informal learning 
processes. The lounge on the second floor, the dining room and outdoor café on the ground floor enable people to discuss anything while they are having a cup of coffee. The company provides lunch in the office so they can have informal discussions during lunchtime. They just need better information systems, like bigger internet bandwidth, improved Lotus Notes intranet applications and bigger database capacity.

\subsection{Effective informal team learning}

Based on the research literature, effective informal team learning is a dependent variable, or the outcome of this study that is usually measured by performance, behaviour, attitude, satisfaction and mission accomplishment. During the interview sessions, interviewees considered faster task accomplishment and capability enhancement as the outcome of informal team learning. Some team leaders from business team mentioned team performance improvement as the other outcome, as shown in Table 4.

As a knowledge-intensive firm, learning is a must, and most of the tasks can only be accomplished by informal learning. Some jobs have no formal training. Formal mentoring and coaching can help, but individuals and teams should learn informally to do their job. Consultants and trainers who rely solely on formal learning cannot execute programs because they have to conciliate the programs to clients.

Informal learning also more quickly improves a team's capability. A team needs to learn fast to be able to propose and deliver solutions. It will take too much time if team members rely on formal training only.

Table 3. Informal learning dimensions developed based team leader and team members' opinion

\begin{tabular}{|c|c|c|c|c|c|}
\hline Variable & Dimensions & Dimensions from Team Leader & Freq. & Dimensions from Team Member & Freq. \\
\hline \multirow{7}{*}{ Informal Learner } & Trustworthy & $\alpha$ & 5 & 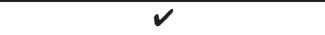 & 13 \\
\hline & Open minded & $\boldsymbol{\nu}$ & 4 & $\boldsymbol{v}$ & 10 \\
\hline & $\begin{array}{l}\text { Eager to learn and share } \\
\text { knowledge }\end{array}$ & $\checkmark$ & 5 & $\checkmark$ & 12 \\
\hline & Take initiative & $\boldsymbol{\nu}$ & 5 & $\boldsymbol{\nu}$ & 8 \\
\hline & Adaptability & & & $\checkmark$ & 5 \\
\hline & Innovative & $\boldsymbol{v}$ & 2 & $\checkmark$ & 9 \\
\hline & & Analytical thinking & 3 & & \\
\hline \multirow{6}{*}{ Team Leadership } & Role model & $\checkmark$ & 5 & $\checkmark$ & 14 \\
\hline & Open & $\boldsymbol{\nu}$ & 3 & 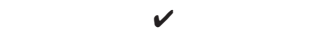 & 8 \\
\hline & Flexible & & & $\checkmark$ & 10 \\
\hline & Giving guidance & $\boldsymbol{V}$ & 3 & $\checkmark$ & 6 \\
\hline & Motivating others to learn & & & $\boldsymbol{v}$ & 7 \\
\hline & & Clear vision & 2 & $\begin{array}{c}\text { Know and develop team members' } \\
\text { strengh }\end{array}$ & 4 \\
\hline \multirow{4}{*}{ Team Climate } & Trust each other & $\checkmark$ & 4 & $v$ & 12 \\
\hline & Openness & $\checkmark$ & 3 & $\checkmark$ & 7 \\
\hline & Learn and share knowledge & $\boldsymbol{\nu}$ & 4 & $\checkmark$ & 13 \\
\hline & Supported system and facilities & $\checkmark$ & 2 & $\checkmark$ & 6 \\
\hline \multirow{3}{*}{$\begin{array}{l}\text { Effective Informal } \\
\text { Team Learning }\end{array}$} & Faster tasks accomplishment & $\checkmark$ & 3 & $\checkmark$ & 9 \\
\hline & Capability enhancement & $\checkmark$ & 5 & $\checkmark$ & 9 \\
\hline & & Performance improvement & 2 & & \\
\hline
\end{tabular}

Table 4. Informal learning dimensions developed based on team function

\begin{tabular}{|c|c|c|c|c|c|c|c|}
\hline Variable & Dimensions & $\begin{array}{l}\text { Dimensions from } \\
\text { Business Team }\end{array}$ & Freq. & $\begin{array}{l}\text { Dimensions from } \\
\text { Technical Team }\end{array}$ & Freq. & $\begin{array}{c}\text { Dimensions from } \\
\text { Support Team }\end{array}$ & Freq. \\
\hline \multirow{7}{*}{ Informal Learner } & Trustworthy & $\checkmark$ & 6 & $\checkmark$ & 7 & $\checkmark$ & 5 \\
\hline & Open minded & $\boldsymbol{V}$ & 3 & $\boldsymbol{V}$ & 6 & $\checkmark$ & 5 \\
\hline & Eager to learn and share knowledge & $\checkmark$ & 5 & $\checkmark$ & 7 & $\checkmark$ & 5 \\
\hline & Take initiative & $\checkmark$ & 4 & $\checkmark$ & 6 & $\checkmark$ & 3 \\
\hline & Adaptability & & & $\boldsymbol{\nu}$ & 4 & $\boldsymbol{V}$ & 1 \\
\hline & Innovative & $\checkmark$ & 3 & $\checkmark$ & 6 & $\checkmark$ & 2 \\
\hline & & Analytical thinking & 2 & Analytical thinking & 1 & & \\
\hline \multirow{2}{*}{ Team Leadership } & Role model & $\checkmark$ & 5 & $\checkmark$ & 7 & $\boldsymbol{v}$ & 7 \\
\hline & Open & $\checkmark$ & 3 & $\boldsymbol{\sim}$ & 7 & & \\
\hline
\end{tabular}




\begin{tabular}{|c|c|c|c|c|c|c|c|}
\hline & Flexible & $\checkmark$ & 4 & $\checkmark$ & 6 & & \\
\hline & Giving guidance & $\checkmark$ & 2 & $\checkmark$ & 4 & $\checkmark$ & 3 \\
\hline & Motivating others to learn & $\checkmark$ & 2 & $\checkmark$ & 3 & $\checkmark$ & 2 \\
\hline & & $\begin{array}{c}\text { Clear vision } \\
\text { Know and develop } \\
\text { team members' } \\
\text { strengh }\end{array}$ & 1 & $\begin{array}{c}\text { Clear vision } \\
\text { Know and develop } \\
\text { team members' } \\
\text { strengh }\end{array}$ & 1 & & \\
\hline \multirow{5}{*}{ Team Climate } & Trust each other & $\checkmark$ & 4 & $\checkmark$ & 6 & $\boldsymbol{V}$ & 6 \\
\hline & Openness & $\checkmark$ & 4 & $\checkmark$ & 5 & $\checkmark$ & 6 \\
\hline & Learn and share knowledge & $\checkmark$ & 5 & $\checkmark$ & 7 & $\checkmark$ & 5 \\
\hline & Supported system and facilities & $\boldsymbol{V}$ & 6 & $\checkmark$ & 5 & $\checkmark$ & 5 \\
\hline & Faster tasks accomplishment & $\checkmark$ & 3 & $\checkmark$ & 5 & $\checkmark$ & 4 \\
\hline \multirow{2}{*}{$\begin{array}{l}\text { Effective Informal } \\
\text { Team Learning }\end{array}$} & Capability enhancement & $\checkmark$ & 4 & $\checkmark$ & 5 & $\checkmark$ & 5 \\
\hline & & $\begin{array}{l}\text { Performance } \\
\text { improvement }\end{array}$ & 2 & & & & \\
\hline
\end{tabular}

\section{Discussion}

Based on the qualitative study above, the consulting firm needs both formal and informal learning. And, since it is a knowledge-intensive firm, informal learning occurs by itself. However informal learning activities frequency is different based on the team function. Employees in business and technical teams need to get knowledge quickly and sharing information immediately for accomplishing tasks, therefore they often do informal learning. But employees in support team less learn informally than other teams because most of their works are routine. And informal learning is very useful for new employees.

During interview sessions, leadership is an important factor in creating an informal learning environment. Team leader said a leader is role model who has to be open, give guidance to their team, has a clear vision and influence others to reach that goal. On the other side, team members expect their leaders to be flexible, know their members' strength and develop its strength through informal learning. Less indicators found in support team function, becoming a role model, giving guidance and motivation are keys for team leader in facilitating informal learning.

In line with literature study, both team leader and team member agrees that the indicators of informal learners are trustworthy, open minded, eager to learn, take initiative and innovative. However some team leaders said the importance of analytical thinking and team members mentioned the importance of adaptability of informal learners.

Informal learning processes need a supporting team climate. People in a team should trust and respect each other, have openness, willing to learn and share knowledge, and be provided with good facilities and systems. This company gets benefits from having company values that support informal learning. It accommodates employees in communicating with respect and sharing information openly, regardless of their position or generation. But interviewees still need better information system to support them to learn informally.

Those three variable, i.e. informal learner, team leadership, and team climate can truly influence informal team learning. The result of this effectiveness is that informal learning can help employees accomplish their tasks faster and improve team performance. It also enhances individual and team capability. Hence, this qualitative study answered the research question.

This study's results can be used as a reference for leaders, to help optimize informal learning in their firm. They can start by encouraging the current leader in becoming a role model, to be open, flexible, giving guidance and motivate others to learn. Having a clear vision and influencing others to reach the vision, and know and develop team members' strength might necessary for some team.

Thus, leader can improve informal learner by emphasizing the importance of informal learning and let them know that being trusted, open minded, eager to learn and share knowledge, take initiative, adaptability and innovative are important indicators of informal learner. Having an analytical thinking will be useful for some teams.

And supporting team climate is also crucial to create and maintain informal learning behaviour. Trust each other, openness, learn and share knowledge, and supported system and facilities are indicators for creating team climate for informal learning. Surely this model can be applied to other organizations; ones that are larger and from other industries.

However, this case study has some limitations. The findings in this study are generally not applicable to people beyond this specific case. Although the observations and interviews of employees were done in-depth, the number of samples is limited. This qualitative case is a preliminary study in this field of research. A more developed model should be studied in the winners of Indonesian Most Admired Knowledge Enterprise (MAKE) Study during 1995-2014 periods. 


\section{Bibliography}

Advanced Distributed Learning (2012). Enabling Next Generation Learning with the Next Generation Learning Architecture. Retrieved from: http://www.adlnet.gov/resources/enabling_next_gen_learning?type=presentation

Arnold, J.A., Arad, S., Rhoades, J.A., \& Drasgow, F. (2000). The empowering leadership questionnaire: The construction and validation of a new scale for measuring leader behaviours, Journal of Organizational Behaviour, 21, 249-269.

Boud, D. \& Middleton, H. (2003). Learning from others at work: communities of practice and informal learning, Journal of Workplace Learning, 15(5), 194-202.

Cheetham, G. \& Chivers, G. (2001). How professionals learn in practice: an investigation of informal learning amongst people working in profession, Journal of European Industrial Training, 25(5), 247-292.

Chivers, G., (2010). Supporting informal learning by traders in investment banks, Journal of European Industrial Training, 35(2), 154175.

Chuang, C.H., Jackson, S.E., \& Jiang, Y. (2013). Can knowledge-intensive teamwork be managed? Examining the roles of HRM systems, leadership and tacit knowledge, Journal of Management, 20(10), 1-31.

Conlon, T.J. (2004). A review of informal learning literature, theory and implications for practice in developing global professional competence, Journal of European Industrial Training, 28(2), 283-295

Coraldyn, D. and Bjornavold, J. (2004). Validation of formal, non-formal, informal learning: policy and practices in EU member state? European Journal of Education, 39(1), 69-89

Cross, J. (2007). Informal Learning: Rediscovering the Natural Pathways That Inspire Innovation and Performance. Pfeiffer Books, John Wiley \& Sons Inc., $10^{\text {th }}$ edition

Cunningham, P. and lles, P. (2002). Managing learning climates in financial services organization, Journal of Management Development, 21(6), 477-492

Edmondson, A. (1999). Psychological safety and learning behaviour in work teams, Administrative Science Quarterly, 44(2), 359-383.

Edmondson, A., Dillon, J.R., \& Roloff, K.S. (2006). Three perspectives on team learning: outcome improvement, task mastery and group process (Working papers). Retrieved from http://www.hbs.edu/faculty/Publication\%20Files/07-029.pdf

Ellinger, D.A. \& Cseh, M. (2007). Contextual factors influencing the facilitation of others' learning through everyday work experiences, Journal of Workplace Learning, 19(7), 435-452

Ghosh, R., Shuck, B. \& Petrosko, J. (2010). Emotional intelligence and organizational learning in work teams, Journal of Management Development, 31(6), 603-619

Gladstein, D. (1984). Groups in context: a model of task group effectiveness, Administrative Science Quarterly, 29(4), $499-517$.

Gola, G. (2009). Informal learning of social workers: a method of narrative inquiry, Journal of Workplace Learning, 21(4), $334-346$

Gorard, S., Fevre, R. \& Rees, G. (1999). The apparent decline of informal learning, Oxford Review of Education, 25(4), 437-456

Hackman, J.R. (1990). Groups that Work (and Those That Don't), Jossey-Bass Publishers, San Francisco, CA, USA

Herre, C. (2010). Promoting team effectiveness: How leaders and learning process influence team outcomes (Unpublished doctoral dissertation). Department of Psychology, University of Fribourg, Germany.

Hult, G.T.M., Kethcen, D.J.Jr., \& Slater, S.F. (2002). A longitudinal study of the learning climate and cycle time in supply chains, Journal of Business \& Industrial Marketing, 17(4), 302-323

Iyer, G.S. \& Ravindran, S. (2009). Usefulness, incentives and knowledge management, Journal of Knowledge Management, 13(6), 410430

Kajewski, K. \& Madsen, V. (2012). Demystifying 70:20:10. (Whitepaper). Retrieved from: https://www.deakinprime.com/deakinprime/ resources/pdf/whitepapers/DeakinPrime_70.20.10_WhitePaper.pdf

Knowledge Advisors (2010). Informal learning measurement. (Whitepaper). Retrieved from: www.knoweldgeadvisors.com

Kostopoulos, K.C. \& Bozionelos, N. (2011). Team exploratory and exploitative learning: psychological safety, task conflict and team performance, Group and Organization Management, 36(3), 385-415

Liu, J., Liu, X, \& Zeng, X. (2011). Does transactional leadership count for team innovativeness? The moderating role of emotional labour and the mediating role of team efficacy, Journal of Organizational Change Management, 24(3), 282-298

Macneil, C. (2001). The supervisor as a facilitator of informal learning in work teams, Journal of Workplace Learning, 13(6), 246-253

Marsick, V.J. \& Watkins, K.E. (1990). Informal and incidental learning, New Direction For Adult and Continuing Education, 89, spring

Marsick, V.J. \& Watkins, K.E. (2003). Demonstrating the value of an organization's learning culture: the dimensions of the learning organization questionnaire, Advances in Developing Human Resources, 5(2), 132-151

Marquardt, M. (2000). Action learning and leadership, The Learning Organization, 7(5), 233-240

McNally, J., Blake, A. \& Reid, A (2009). The informal learning of new teachers in school. Journal of Workplace Learning, 21(4), 322-333

Nailon, D., Delahaye, B., \& Brownlee, J. (2007). Learning and leading: how beliefs about learning can be used to promote effective leadership, Development and Learning in Organizations, 21(4), 6-9

Nirmala, M. \& Vemuri, M. (2009). Leveraging informal networks in knowledge management, Journal of Knowledge Management, 13(3), 146-156

Prugsamatz, R. (2010), Factors that influence organizational learning in non-profit organizations, The Learning Organization, 17(3), 243267

Reardon, R.F. (2004), Informal learning after organizational change, Journal of Workplace Learning, 16(7), 385-395

Reardon, R.F. (2009), The impact of learning culture on worker response to new technology, Journal of Workplace Learning, 22(4), 201- 
211

Reychav, I. \& Weisberg, J. (2009). Bridging intention and behaviour of knowledge sharing, Journal of Knowledge Management, 14(2), 285-300

Ross, T.M, Jones, E.C. \& Adams, S.G. (2008), Can team effectiveness be predicted?, Team Performance Management, 14(5/6), 248268

Ryan, G., Emmerling, R.J. \& Spencer, L. M. (2009). Distinguishing high-performance European executives: the role of emotional, social and cognitive competencies, Journal of Management Development, 28(9), 859-875

Senge, P., Roberts, C., Ross, R., Smith B.L. \& Kleiner, N. A. (1990). The Fifth Discipline Field book: Strategies and Tools for Building a Learning Organization. New York, NY: Doubleday, $1^{\text {st }}$ edition

Srivastava, A., Bartol, K.M. \& Locke, E.A. (2006). Empowering leadership in management teams: effects on knowledge sharing, efficacy and performance, Academy of Management Journal, 49(6), 1239-1251

Svensson, L., Ellstrom, P-E; \& Aberg, C. (2004). Integrating formal and informal learning at work, Journal of Workplace Learning, 16(8), $479-491$

Tjakraatmadja, J.H. \& Lantu, D.C. (2006). Knowledge Management in Learning Organization Context. Bandung: SBM-ITB Publishing, Indonesia

Yin, R.K. (1994). Case Study Research: Design and Methods. CA: Sage Publications, $2^{\text {nd }}$ edition. 